\title{
KONTRIBUSI PRODUK SEKUNDER AMPAS TAHU PADA USAHA INDUSTRI RUMAH TANGGA UD. DUA PUTRI DI DESA GUNUNG ANTASARI KECAMATAN SIMPANG EMPAT KABUPATEN TANAH BUMBU PROVINSI KALIMANTAN SELATAN
}

(Seconder Product Contribution of Tofu Dregs UD Dua Putri Home Industries in Gunung Sari Village Simpang Empat Subdistrict Tanah Bumbu Regency City South Kalimantan Province)

\section{Fitri Mahyudi dan Husinsyah}

Program Studi Agribisnis Fakultas Pertanian Universitas Achmad Yani Banjarmasin

Email:fitri.mahyudi@yahoo.co.id, husinactivities@gmail.com

Article Submitted : 01-3-2020

Article Accepted : 03-6-2020

\begin{abstract}
This Research aim to know technically about Seconder Product Contribution of Tofu Dregs UD Dua Putri Home Industries in Gunung Sari Village Simpang Empat Subdistrict Tanah Bumbu Regency City South Kalimantan Province. From result of knowable analysis that level of amount of acceptance from result of processing know Rp. 5.040.000/day and Rp. 151.200.000/month. Others at this tofu home industry there are addition of acceptance from tofu dregs know yield up with detail in 1 day yield $230 \mathrm{~kg} /$ day and $6.900 \mathrm{~kg}$ dregs each month. Price sell tofu dregs know per kg Rp.1.000,-, hence result of total acceptance from tofu dregs know equal to Rp. 230.000/day and Rp.6.900.000/month. Become total acceptance from effort UD. Two Putri tofu home industry equal to Rp.5.270.000,-/Hari and Rp. 158.100.000,-/month. From result analyse known benefit effort processing know equal to Rp. 61.508.652,79,/month.
\end{abstract}

Key words : Seconder Product, Tofu Dregs, Cost, Revenue, Contribution

\section{PENDAHULUAN}

Kacang kedelai atau dalam bahasa latin disebut dengan Glycine Max atau dikenal dengan kedelai kuning dan Glycine soja bisa juga disebut dengan kedelai hitam. Tanaman ini memiliki akar yang berbintilbintil dengan fungsi sebagai pengikat nitrogen bebas yang banyak mengandung gizi seperti protein, lemak dan vitamin dan selain itu juga dapat digunakan sebagai pupuk organik dan pakan ternak (Kementrian Pertanian, 2016).

Kedelai dapat diolah menjadi beberapa bentuk seperti tempe, tahu, tauco, susu kedelai, kecap, tepungkedelai dan juga dalam bentuk minyak yang mana digunakan sebagai bahan dasar olahan seperti alat kecantikan, minyak, plastik, bahan dasar alat tulis, warna, pelarut dan biodisel. Data dari SUSENAS ( Survey Sosial Ekonomi Nasional) pada tahun 2015 menunjukan hasil bahwa angka konsumsi tahu lebih tinggi dari angka konsumsi tempe yaitu sebesar 7,51 Kg sedangkan tempe hanya $6,99 \mathrm{Kg}$ rata-rata perorang per tahun (Kementrian Pertanian, 2016)

Salah satu hasil olahan makanan berbahan baku kedelai adalah tahu yang mana proses pembuatannya didapatkan dari sari dari kacang kedelai yang telah dimasak dan dicampur dengan bahan penggumpal lainya seperti asam cuka dan ion kalsium (Cahyadi,2006). 
Ampas tahu merupakan hasil sampingan dari proses pembuatan tahu. Kadar protein ampas tahu cukup tinggi yakni sekitar $6 \%$. Pada umumnya ampas tahu dimanfaatkan untuk pakan ternak atau campuran oncom dan tempe gembus. Ampas tahu memiliki peluang untuk digunakan dalam pembuatan tepung kaya serat protein yang dapat diaplikasikan pada berbagai produk pangan dan sebagai media tumbuh dan perkembangan jamur dan mampu menghasilkan kadar protein 61,14 \% (Nana Nurdjannah, Sri Usmiati, 2006).

Usaha Pengolahan Tahu terus berkembang pesat, walau pelaku usaha masih banyak yang kurang memahami akibat yang ditimbukan seperti pencemaran lingkungan, kurangnya pengetahuan bahan yang digunakan (ramah lingkungan), belum terkelola dengan baik hasil residu pengolahan tahu yaitu ampas tahu, padahal bila dikelola dengan baik, produk residu/sekunder akan bermanfaat dan menambah pendapatan pengusaha pengolahan tahu (Ida Widaningrum, 2015).

Peluang usaha yang bergerak dalam produksi pembuatan tahu sangat baik untuk dikembangkan karena proses produksinya sangat mudah yaitu baik secara modern (alat) dan secara tradisional (masih menggunakan tenaga manusia) dengan ampas tahu sebagai produksi sekundernya yang biasa digunakan sebagai pakan ternak. Industri pengolahan tahu cukup banyak berkembang di Kalimantan selatan. Namun beberapa industri pembuatan tahu tidak beroperasi lagi untuk saat ini dan hanya sedikit yang masih beroperasi.

\section{METODE PENELITIAN}

\section{Waktu dan Tempat}

Penelitian ini dilaksanakan di UD. Dua Putri yang berlokasi di Desa Gunung Antasari Kecamatan Simpang Empat Kabupaten Tanah Bumbu Provinsi Kalimantan Selatan selama 3 bulan mulai bulan Desember 2019 - Februari 2020, yaitu dari tahapan persiapan sampai menyusun laporan.

\section{Metode Pengumpulan Data}

Data yang diperoleh kemudian diolah, selanjutnya dianalisis secara deskriptif, dan dilakukan analisis finansial (Santoso, 2005). Menggunakan metode pengambilan data yaitu metode purposive sampling dimana dipilih secara sengaja UD. Dua Putri sebagai sampel penelitian karena usaha tersebut terus beroperasi selama 5 (lima) tahun terakhir.

\section{Analisis Data}

Menurut Soekartawi, (2006), biaya total, yaitu keseluruhan jumlah biaya produksi yang dikeluarkan. Secara matematis biaya total dapat dirumuskan sebagai berikut:

$$
\text { TC }=\text { TFC }+ \text { TVC }
$$

Keterangan :

TC $($ Total Cost $) \quad=$ Biaya Total $(\mathrm{Rp})$ TFC $($ Total Fixed Cost $)=$ Total Biaya Tetap (Rp)

TVC $($ Total Variable Cost $)=$ Total Biaya Variabel (Rp)

Menurut Abdul Rasul, Agung (2013), penerimaan total secara langsung ditentukan oleh jumlah produk yang terjual dan yang diterima. Secara matematis penerimaan total dapat dirumuskan sebagai berikut:

$$
\mathbf{T R}=\mathbf{P} \times \mathbf{Q}
$$

Keterangan :

TR $($ Total Revenue $) \quad=$ Penerimaan total

$$
\text { (Rp) }
$$

$\mathrm{P}$ (Price) = Harga produk $(\mathrm{Rp})$

$\mathrm{Q}$ (Quantity)= Jumlah produk $(\mathrm{Kg})$

Menurut Syarifuddin A. Kasim (1995), untuk menentukan tingkat pendapatan maka dianalisis secara tabulasi sederhana dengan menggunakan rumusan sebagai berikut :

$$
\mathbf{I}=\mathbf{T R}-\mathbf{T V C}
$$

Keterangan :

I $($ Total Revenue $)=$ Pendapatan Total $(\mathrm{Rp})$

TR $($ Total Revenue $)=$ Penerimaan Total (Rp)

TVC $($ Total Variable Cost $)=$ Biaya Variabel Total (Rp) 
Menurut Ronny (2010), untuk menentukan tingkat keuntungan maka dianalisis secara tabulasi sederhana dengan menggunakan rumusan sebagai berikut :

$$
\boldsymbol{\pi}=\mathbf{T R}-\mathbf{T C}
$$

Keterangan :

$$
\begin{aligned}
\pi & =\text { Keuntungan }(\mathrm{Rp}) \\
\mathrm{TR}(\text { Total Revenue })= & \text { Penerimaan Total } \\
& (\mathrm{Rp}) \\
\mathrm{TVC}(\text { Total Cost })= & \text { Biaya Total }(\mathrm{Rp})
\end{aligned}
$$

\section{HASIL DAN PEMBAHASAN}

Usaha pembuatan dan penjualan tahu dimulai sejak tahun 2006 yang dikenal dengan nama UD. Dua Putri. Industri pembuatan tahu ini beralamatkan di Desa Gunung Antasari Kecamatan Simpang Empat Kabupaten Tanah Bumbu. Usaha ini dikelola oleh Bapak Matlikan tenaga kerja yang ada dalam industri pembuatan tahu ini berasal dari beberapa daerah baik dari pulau Kalimantan ataupun pulau Jawa. Usaha ini dilakukan dengan alasan karena banyaknya permintaan tahu dan merupakan industri usaha tahu satu-satunya yang berkembang di Desa Gunung Antasari Kecamatan Simpang Empat.

Tahu kedelai dibuat dengan cara mengendapkan protein dari kedelai dengan menggunakan bahan penggumpal yaitu $\mathrm{CaSO}_{4}$ atau biasa disebut sisoko. Sisoko berasal dari gips yang mengandung kalsium sulfat yang dibakar dan ditumbuk halus dan juga menggunakan asam cuka $90 \%$ (Prasetyo Adhi Bintoro, 2017).

Proses pembuatan tahu melalui beberapa tahapan, yaitu:

1. Penyortiran, manfaatnya untuk memisahkan kacang lain yang tercampur dengan biji kacang kedelai serta memisahkan biji kacang kedelai yang bagus dan yang sudah rusak agar menjadikan biji kedelai yang berkualitas.

2. Pembersihan, biji kedelai harus dicuci dengan bersih untuk menghilangkan kotoran yang bercampur dengan kacang kedelai.
3. Perendaman, setelah dicuci bersih kacang kedelai direndam dalam drum selama 3 jam.

4. Penggilingan, setelah direndam kacang kedelai kemudian ditiriskan lalu masuk kedalam tahap penggilingan menggunakan mesin penggiling.

5. Perebusan, hasil gilingan kacang kedelai selanjutnya direbus menggunakan drum besi dengan ditambahkan air. Hasil gilingan direbus hingga masak menggunakan tabung dari mesin uap.

6. Penyaringan, setelah hasil gilingan direbus maka tahapan selanjutnya adalah memisahkan sari kedelai dengan ampasnya menggunakan kain saring, Setelah itu ampas disisihkan dan dipindahkan kedalam drum plastik.

7. Penambahan bahan berupa cuka, sari kacang kedelai hasil proses penyaringan ditambahkan bahan berupa cuka yang berfungsi sebagai zat koagulasi atau untuk membantu penggumpalan/pengendapan.

8. Pencetakan, hasil endapan sari kacang kedelai dimasukan dalam cetakan kayu yang sudah disiapkan kemudian di press untuk menghasilkan bentuk yang lebih pipih.

9. Pemotongan, setelah tahu dicetak dengan ukuran cetakan panjang 100 $\mathrm{cm}$ dan lebar $70 \mathrm{~cm}$, maka proses akhir pada pembuatan tahu adalah pemotongan tahu yang dapat dibuat menjadi 3 ukuran yaitu kecil ( P: 4,5 $\mathrm{cm}$ dan L: $3,5 \mathrm{~cm}$ ), sedang (P: $5,5 \mathrm{~cm}$ dan L: $4,5 \mathrm{~cm}$ ) dan besar (P: 7,5 cm dan L: $6,5 \mathrm{~cm}$ ) dengan rata-rata ketebalan tahu $2 \mathrm{~cm}$. Pada Pembuatan tahu UD. Dua Putri untuk ukuran kecil dalam satu cetakan didapatkan 300 biji, ukuran sedang sebanyak 260 biji dan ukuran besar sebanyak 150 biji. Proses pembuatan tahu dan residu ampas tahu sesuai dengan SOP 
kesehatan dan keselamatan kerja produk UKM (Koswara, S. 1992)

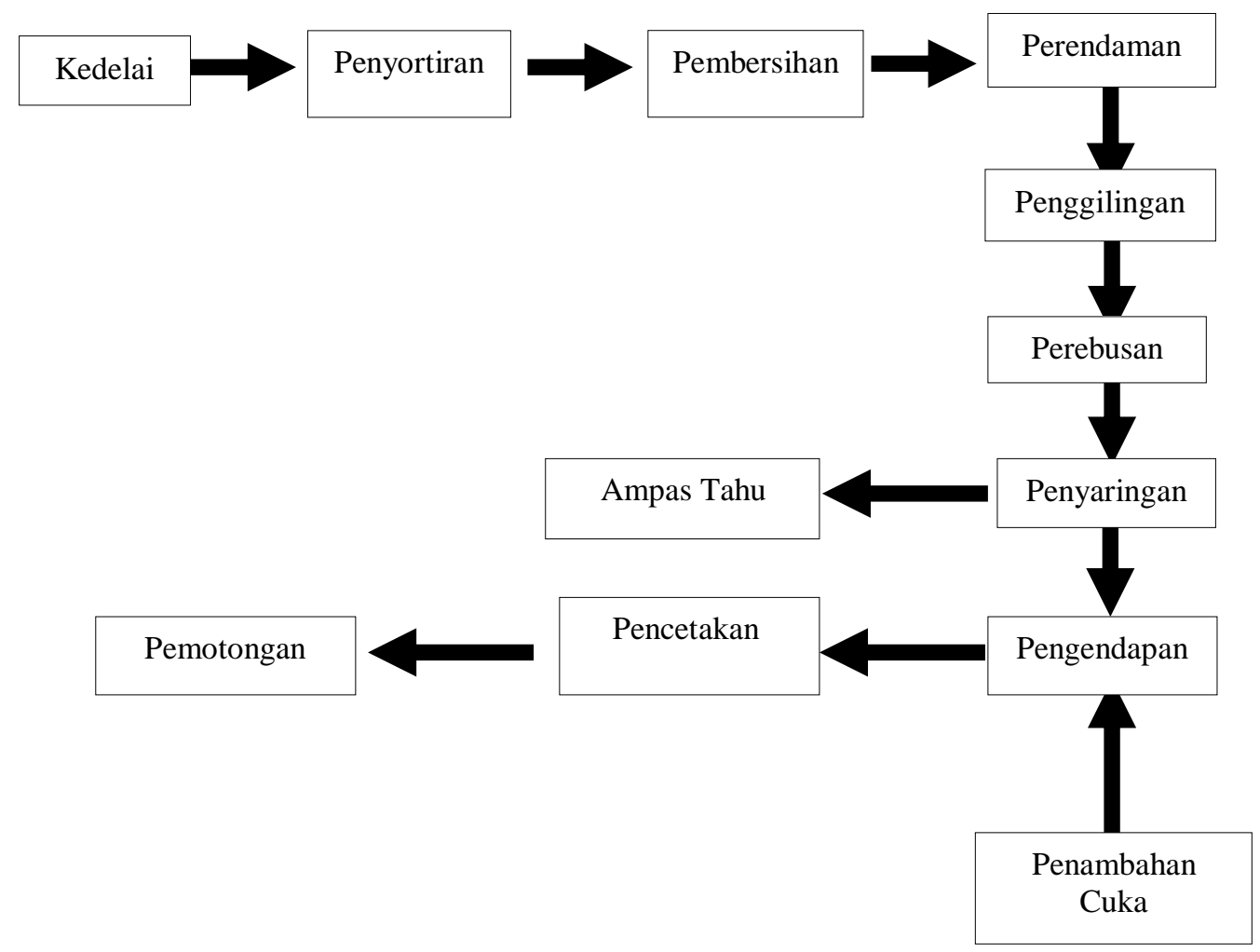

Gambar 1. Proses Pembuatan Tahu

Berdasarkan penelitian Jaka Darma Jaya, dkk (2018) menjelaskan bahwa produk bersih tahu menimbulkan ceceran kedelai pada saat penggilingan sebanyak $4 \mathrm{~kg}$, limbah padat berupa ampas tahu sebesar 210 $\mathrm{kg}$ dan total limbah cair sebesar $2.115,5 \mathrm{~kg}$. Limbah padat ampas tahu dimanfaatkan menjadi tempe gembus dan paka ternak sedangkan limbah cair pengolahan tahu dimanfaatkan menjadi pupuk organik dan biogas.

\section{Biaya Penyusutan Alat}

Sehubungan dengan berkurangnya nilai pakai alat-alat produksi pembuatan usaha tahu, maka dapat dilakukan perhitungan biaya penyusutan alat-alat yang tahan lama dan mengandung sejumlah nilai pakai yang harus diperhitungkan setiap tahunnya. Biaya penyusutan ini tergantung pada nilai alat saat pembelian, usia ekonomis alat, nilai sisa setelah habis jangka ekonomis tersebut (dalam hal ini dianggap nol) dan masa kerja efektif alat pada usaha pembuatan tahu.

Hasil pengolahan data diperoleh biaya total untuk penyusutan alat sebesar Rp. 1.026.666,65. Berdasarkan Tabel 2 bahwa biaya penyusutan alat paling besar adalah pada penggunaan drum plastik Rp. 218.750,dan biaya penyusutan paling kecil ada pada penggunaan penggaris Rp.1.250,--

\section{Biaya Tenaga Kerja}

Biaya tenaga kerja juga diperhitungkan karena mempengaruhi keuntungan usaha pembuatan tahu Industri UD. Dua Putri. Upah karyawan yang dikeluarkan dalam 1 bulan adalah $\mathrm{Rp}$. 2.500.000,-, jadi total pengeluaran upah dalam 1 bulan untuk 4 orang karyawan adalah Rp. 10.000.000,-

\section{Biaya Listrik}

Biaya listrik yang dikeluarkan dalam pembuatan usaha tahu ini adalah sebesar Rp. 200.000,-/bulan. Pada usaha ini listrik 
digunakan hanya sebagai penerangan dan untuk pompa air yang mana air tersebut digunakan untuk proses pencucian kacang kedelai, perendaman dan pencucian alat-alat yang digunakan pada saat industri.

Tabel 2. Biaya Penyusutan Alat dan Perlengkapan Rata-Rata Usaha Tahu

\begin{tabular}{clr}
\hline NO & \multicolumn{1}{c}{ URAIAN } & BIAYA (Rp) \\
\hline 1 & Mesin giling & 200.000 \\
2 & Mesin uap \& tabung uap & 200.000 \\
3 & Kain saring & 140.000 \\
4 & Drum besi & 50.000 \\
5 & Cetakan & $145.833,33$ \\
6 & Pisau & 6.250 \\
7 & Penggaris & 1.250 \\
8 & Pompa air & $16.666,66$ \\
9 & Drum plastik & 218.750 \\
10 & Baskom & $29.166,66$ \\
11 & Pengaduk kayu & 18.750 \\
\hline & & JUMLAH
\end{tabular}

Sumber: Pengolah Data November (2019)

\section{Biaya Pemasaran}

Biaya pemasaran usaha tahu milik Bapak Matlikan dijual langsung oleh pemilik usaha di Pasar Subuh Kodeco Batulicin dengan menggunakan alat angkut berupa kendaraan pribadi. Biaya yang digunakan dalam 1 hari yaitu 2 liter bahan bakar dengan harga Rp. 7.350,-/liter.
Dengan demikian jumlahbiaya angkut tahu keseluruhan adalah Rp. 14.700,-/hari dan Rp. 441.000,/bulan.

\section{Biaya Total Produksi}

Biaya Total Produksi merupakan penjumlahan anatar biaya tetap dan biaya variabel.

Tabel 3. Biaya Total Produksi dalam satu periode produksi ( 1 bulan)

\begin{tabular}{clr}
\hline No & Biaya (Rp) & \multicolumn{1}{c}{ Jumlah (Rp) } \\
\hline 1 & Biaya Tetap & $1.200 .347,21$ \\
2 & Biaya Variabel & 95.391 .000 \\
\hline \multicolumn{2}{r}{ Biaya Total } & $96.591 .247,21$ \\
\hline
\end{tabular}

Sumber: Pengolah Data November (2019)

Berdasarkan Tabel 3 Dapat diketahui bahwa biaya total produksi usaha tahu UD. Dua Putri adalah sebesar Rp. 96.591.247,21,- yang terdiri dari biaya tetap sebesar Rp. 1.200.347,21,- dan biaya variabel sebesar Rp. 95.391.000,- .

\section{Biaya Implisit dan Eksplisit}

Biaya Eksplisit adalah jumlah pengeluaran yang dikeluarkan dalam kegiatan produksi. Adapun contoh biaya eksplisit yang ada dalam penelitian ini adalah seperti: biaya bahan baku, biaya penyusutan alat, biaya upah karyawan selain anggota keluarga, biaya listrik, biaya pemasaran, dll. Adapun biaya-biaya tersebut dalam penelitian ini sudah termasuk kedalam kategori biaya total variabel.

Biaya implisit yaitu biaya yang tidak nyata dikeluarkan tetapi tetap diperhitungkan karena berdampak pada 
biaya produksi. Adapun contoh yang termasuk biaya implisit adalah biaya tenaga kerja dalam keluarga (TKDK), biaya sewa tempat milik sendiri, biaya modal sendiri, dll. Namun, dalam penelitian ini tidak dilakukan perhitungan besaran biaya implisit karena tidak ada bagian anggota keluarga yang terlibat dalam proses produksi, dan tempat produksi serta modal dimiliki secara mandiri oleh pelaku usaha tahu UD. Dua Putri.

\section{Penerimaan dan Kuntungan} Penerimaan Pembuatan Usaha Tahu

Bahan baku kacang kedelai yang digunakan sebanyak $300 \mathrm{Kg}$ setiap hari dapat menghasilkan 72 cetakan tahu. Dari 1 Cetakan ukuran P: $100 \mathrm{~cm}, \mathrm{~L}: 70 \mathrm{~cm}$ dan rata-rata ketebalan tahu $2 \mathrm{~cm}$ tahu dijual dengan harga Rp.70.000,-. Setiap cetakan tahu dapat dipotong menjadi 3 ukuran yaitu kecil ( P: 4,5 cm dan L: 3,5 cm), sedang (P: $5,5 \mathrm{~cm}$ dan L: $4,5 \mathrm{~cm})$ dan besar $(\mathrm{P}: 7,5 \mathrm{~cm}$ dan L: $6,5 \mathrm{~cm}$ ) dengan jumlah masingmasing potongan yaitu potongan besar ( 150 biji), potongan sedang (260 biji) dan potongan kecil (300 biji).

\section{Keuntungan Usaha Pembuatan Tahu}

Keuntungan adalah hasil dari
pengurangan penerimaan total dan
pengeluaran total yang diperoleh pada
periode tertentu. Dari hasil analisis
diketahui keuntungan pada usaha
pengolahan tahu adalah sebesar Rp.
61.508.652,79,-/bulan.

\section{Kontribusi keuntungan ampas tahu}

Dari hasil analisis dapat diketahui bahwa besarnya jumlah penerimaan dari hasil pengolahan tahu adalah $\mathrm{Rp}$. 5.040.000,-/hari dan Rp. 151.200.000,/bulan. Selain itu pada industri ini terdapat tambahan penerimaan dari ampas tahu hasil produksi dengan rincian dalam 1 hari menghasilkan $230 \mathrm{Kg}$ ampas tahu dan 6.900 $\mathrm{Kg}$ ampas tahu setiap bulan. Harga jual ampas tahu per $\mathrm{Kg}$ adalah Rp.1.000,-, maka hasil penerimaan dari ampas tahu sebesar Rp. 230.000,-/hari dan Rp.6.900.000,-/bulan.
Jadi penerimaan total dari usaha industri UD. Dua Putri adalah sebesar Rp.5.270.000,-/hari dan Rp. 158.100.000,/bulan.

Hasil penelitian Nana Nurdjannah dan Sri Usmiati (2006) menjelaskan bahwa ampas tahu basah menghasilkankonsentrat protein dengan kualitas yang lebih baik disbanding ampas tahu kering dengan rendemen menunjukkan suhu ekstraksi $50^{\circ} \mathrm{C}$ dan $\mathrm{pH} 10$ mempengaruhi karakteristik pada rendemen tepung $11,68 \%$, recovery protein $25,85 \%$, kadar air $6,66 \%$ dan daya serap air 3,38 gram air/gram protein.

Hasil penelitian Melkias Londo, Benu Theodora (2017) menerangkan bahwa total produksi tahu dengan 10 responden di Kecamatan Malalayang Kota Manado Provinsi Sulawesi Utara sebesar 1.498 ember/minggu dengan kentungan yang diperoleh dari usaha tahu sebesar $\mathrm{Rp}$. 47.014.941, 27.

Hasil penelitian Tuso Wiyono dan Rukavina (2014) menerangkan bahwa total pendapatan pada usaha tahu industri rumah tangga UD Wijayanto di Desa Ogurandu Kecamatan Bolano Lambunu Kabupaten Parigi Moutong Provinsi Sulawesi Tengah selama bulan Agustus 2014 sebesar Rp 10.414.786,6 dengan nilai tambah tahu yang diperoleh sebesar Rp. 10.337,72/kg.

Hasil penelitian Wiji Santoso dan Pujiati Utami (2009) menerangkan bahwa total biaya produksi untuk satu kali produksi pada usaha tahu di Desa Pandan Sari Kecamatan Ajibarang Kabupaten Banyumas sebesar Rp. 320.288,30 dengan pendapatan bersih yang diperoleh sebesar $\mathrm{Rp}$. 72.313 .700

\section{KESIMPULAN DAN SARAN}

\section{Kesimpulan}

Berdasarkan hasil penelitian terhadap usaha pengolahan tahu dan ampas tahu, maka dapat diambil beberapa kesimpulan sebagai berikut :

1. Dilihat dari teknis penyelenggaraan usaha pengolahan tahu dan ampas 
tahu masih relatif sederhana, ini terlihat dari pengolahan bahan baku sampai pengolahan bahan sisa/residu yaitu ampas tahu yaitu dari tahap penyortiran bahan baku sampai dengan pencetakan.

2. Dari hasil analisis diketahui keuntungan pada usaha pengolahan tahu UD Dua Putri di Desa Gunung Antasari Kecamatan Simpang Empat adalah sebesar Rp. 61.508.652,79,/bulan.

3. Dari hasil analisis dapat diketahui bahwa besarnya jumlah penerimaan dari hasil pengolahan tahu adalah Rp. 5.040.000,-/hari dan Rp. 151.200.000,-/bulan. Selain itu pada industri ini terdapat tambahan penerimaan dari ampas tahu hasil produksi dengan rincian dalam 1 hari menghasilkan $230 \mathrm{Kg}$ ampas tahu dan $6.900 \mathrm{Kg}$ ampas tahu setiap bulan. Harga jual ampas tahu per Kg adalah Rp.1.000,-, maka hasil penerimaan dari ampas tahu sebesar Rp. 230.000,/hari dan Rp.6.900.000,-/bulan. Jadi penerimaan total dari usaha industri UD. Dua Putri adalah sebesar Rp.5.270.000,-/hari dan Rp. 158.100.000,-/bulan.

\section{Saran}

Perlunya pelatihan kepada pengusaha tahu dalam penggunaan bahan agar tidak menimbulkan pencemaran dan perluasan daerah pemasaran tahu agar pendapatan usaha tahu ini semakin meningkat seperti hingga keluar Kabupaten Tanah Bumbu dan sekitarnya. Untuk meningkatkan keuntungan dan pengembangan usaha tahu sebaiknya pemerintah melakukan pendampingan usaha seperti ikut berperan aktif dalam mempromosikan hasil produksi dan bantuan modal.

\section{DAFTAR PUSTAKA}

Abdul Rasul, Agung.2013. Ekonomi mikro. Jakarta: Mitra Wacana Media
Cahyadi, W. 2006. Kedelai Khasiat dan Teknologi. Jakarta: Bumi Aksara.

Ida Widaningrum, 2015. Teknologi Pembuatan Tahu Yang Ramah Lingkungan. Jurnal Dedikasi Vol.12 Mei 2015. UMM. Malang

Jaka Darma Jaya, dkk. 2018. Perencanaan Produksi Bersih Industri Pengolahan Tahu di UD. Sumber Urip Pelaihari. Jurnal Agroindustri. Vol.8 No.2 Nopember 2018. Polteknik Tanah laut. Pelaihari

Kementrian Pertanian, 2016. Outlook Komoditas Pertanian Tanaman Pangan (Kedelai). Jakarta: Pusat Data Dan Sistem Informasi Pertanian Kementrian Pertanian.

Koswara, 1992. Teknologi Pengolahan Kedelai. Pustaka Sinar Harapan. Jakarta

Melkias Londo, Benu Theodora, 2017. Analisis Keuntungan Pengrajin Tahu Berdasarkan Cara Pembayaran di Kecamatan Malalayang Kota Manado Provinsi Sulawesi Utara. Jurnal Agri Sosek Unsrat Volume 13 No.1 Januari 2017. Manado

Nana Nurdjannah, Sri Usmiati, 2006. Jurnal Pasca Panen Balitbang Pertanian RI Vo.3 No.2 tahun 2006. Jakarta

Prasetyo Adhi Bintoro, dkk. 2017. Pembuatan tahu Rumahan Khas Ledok Kulon. Jurnal Pemberdayaan Vo.1 No.2 Tahun 2017. Universitas Ahmad Dahlan Yogyakarta.

Ronny, 2010. Pendapatan Usahatai Campuran. Seminar hasil Penelitian 
Fakultas Pertaniaan UNSRAT Manado.

Santoso, 2005. Metodologi Penelitian Kualitatif dan Kuantitatif. Jakarta: Gramedia.

Soekartawi, 2006. Analisis Usahatani. Jakarta:Universitas Indonesia

Syarifuddin A. Kasim 1995. Pengantar Ekonomi Produksi Pertanian Universitas Lambung Mangkurat Banjarbaru.
Tuso Wiyono dan Rukavina ,2014. Analisis Pendapatan Dan Nilai Tambah Usaha Tahu Industri Rumah Tangga Wijayanto di Desa Ogurandu Kecamatan Bolano Lambunu Kabupaten Parigi Moutong Provinsi Sulawesi Tengah. Jurnal Agrotekbis Vol.3 Juni 2015 Universitas Tadulako. Palu.

Wiji Santoso dan Pujiati Utami, 2009. Analisis Pendapatan dan Biaya Produksi Agroindustri Tahu Di Desa Pandan Sari Kecamatan Ajibarang Kabupaten Banyumas Provinsi Jawa Tengah. Jurnal Agritech Vol.XI No.1 Juni 2009. Purwokerto 